УДК 347.124

DOI https: / / doi.org/10.32837 / yuv.v0i4.977

\title{
В. Погребняк,
}

суддя

Касаційного господарського суду у складі Верховного Суду, кандидат юридичних наук, докторант кафедри цивільного права № 2

Національного юридичного університету імені Ярослава Мудрого

\section{СПІВВІДНОШЕННЯ МІЖ ЗОБОВ'ЯЗАЛЬНО- ПРАВОВИМ ТА РЕЧОВО-ПРАВОВИМ ПРАВОЧИНАМИ В СВІТЛІ ПРИНЦИПІВ РОЗ'ЄДНАННЯ ТА АБСТРАКЦІї}

\begin{abstract}
Постановка проблеми. Принципи роз'єднання та абстракції є базовими засадами розмежування зобов'язально-правового (зобов'язального) та речово-правового (речового, розпорядчого) правочинів в механізмі переходу суб'єктивних цивільних прав. Вони $є$ результатом осмислення німецькими вченими-пандектисками юридичного механізму виникнення суб'єктивних цивільних прав на підставі цивільно-правового договору в контексті римського приватного права. Декілька років тому це питання було піднято на сторінках літератури відомими вітчизняними вченими юристами і наразі його обговорення активно набирає оберти. Однак, до сих пір вчена спільнота не сформувала єдиної позиції стосовно правової природи такого виду правочинів і взагалі стосовно життєздатності відповідної наукової теорії у вітчизняних правових реаліях.
\end{abstract}

Аналіз останніх досліджень i публікацій. В цивільно-правовій літературі питання співвідношення між зобов'язально-правовим та речово-правовим правочинами розглядалось такими вченими правниками як: В. І. Борисова, П. А. Варул, Б. Віндшейд, Г. Дернбург, Г. Ф. Дормідонтов, Ю. П. Єгоров, С. С. Каширський, А. В. Коструба, Л. В. Криволапова, Н. С. Кузнєцова, Р. А. Майданик, Є. Я. Мотовиловкер, Д. В. Носов,
О. О. Останіна, О. О. Отраднова, М. Д. Пленюк, В. О. Рясенцев, I. В. Спасибо-Фатєєва, О. А. Суржекно, Р. І. Таш'ян, В. С. Толстой, В. А. Фогель, Г. Г. Харченко, Б. Б. Черепахін, С. І. Шимон, О. О. Ягельницький, В. Л. Яроцький та ін.

Постановка завдання. Мета статті полягає у здійсненні аналізу основних положень наукової концепції розмежування зобов'язально-правового та речово-правового (розпорядчого) правочинів в контексті принципів роз'єднання та абстракції з метою визначення їх теоретичної обгрунтованості та перспектив впровадження у вітчизняній правовій системі України.

Основний матеріал дослідження. Принцип роз'єднання, що передбачає розмежування зобов'язально-правового та речово-правового правочинів в механізмі переходу суб'єктивних цивільних прав на речі, а також принцип абстракції, що встановлює відносну незалежність речово-правового правочину від зобов'язально-правового є взаємодоповнюючими і розглядаються в поєднанні. При цьому вони детермінують зв'язки між зобов'язально-правовим та речово-правовим правочинами як складовими юридичного механізму переходу суб'єктивних цивільних прав. Тобто в такому механізмі відповідні правочини в світлі зазначених принципів також розглядаються як взаємодоповнюючі. 
В контексті зазначених принципів німецьке цивільне право розрізняє зобов'язальні правочини, які створюють зобов'язання, та розпорядчі правочини, які безпосередньо переносять титул [1, с. 153]. Наприклад, договір купівлі-продажу є зобов'язально-правовим і породжує зобов'язання з передачі майна у власність. Для переходу права власності необхідне вчинення речово-правового (розпорядчого) правочину [2, с. 383] - домовленості сторін про перехід речових прав [3, с. 7], за якою річ передається набувачу i сторони погоджуються, що право переходить до набувача [4, с. 211].

В юридичній літературі відмічається, що критики принципу роз'єднання та принципу абстракції вважають розмежування зобов'язального та розпорядчого правочинів штучним, оскільки воно ускладнює застосування права [5, с. 41]. Однак, вважаємо, що питання повинно полягати не в складності відповідної конструкції, а в їі життєздатності в контексті нормативних положень, та доцільності в аспекті механізму правового регулювання визначених суспільних відносин.

Більше того, навіть нормативна основа розмежування зобов'язального та розпорядчого правочинів не повинна зупиняти вченого у всебічному іï аналізі, зокрема і в контексті визначення доцільності іï існування. Адже, як справедливо зазначає В. Л. Яроцький, ефективним $€$ використання в галузевих юридичних дослідженнях формально-догматичного методу з позицій конструктивного критично-правового підходу, який дозволяє встановити «слабкі місця» відповідних нормативних положень і, за необхідності, запропонувати шляхи їх усунення [6, с. 8-9]. Саме тому всебічний погляд на порушене питання здатен виявити як переваги, так і недоліки відповідної наукової концепції і визначити перспективи ii розвитку в рамках вітчизняної правової системи.

Переваги і недоліки розмежування зобов'язально-правового та речово-пра- вового правочинів пов'язуються з двома базовими тезами: 1) взаємодоповненням принципів роз'єднання та абстракціi; 2) розумінням правочину як діï, спрямованої на набуття, зміну або припинення цивільних прав та обов'язків.

Саме принцип абстракції в силу своєї неусталеності і недовершеності породжує багато дискусійних моментів аналізованої наукової концепції. Зокрема, Г. Г. Харченко зазначає, що зміст принципу абстракції передбачає, що речовий правочин цивільно-правового договору, за яким відбувається перехід речового права на об'єкт, вважається, як правило, дійсним незалежно від дійсності зобов'язальної частини такого договору. Тобто у випадку, якщо зобов'язальна частина договору буде визнана недійсною, недійсність речової його частини не настає автоматично [4, с. 212]. Сам підхід вченого в межах якого він поєднує «речову частину» та «зобов'язальну частину» в рамках одного договору вже показує відсутність абсолютної незалежності між двома відповідними частинами та їх пов'язаність.

Крім того, В. А. Фогель також непрямо визнає залежність розпорядчого правочину від зобов'язально-правового, зазначаючи, що при недійсності зобов'язально-правового правочину речово-правовий (розпорядчий) залишається дійсним, незважаючи на те, що перший є правовою підставою для другого [2, с. 381]. Тобто, крім того, що обидва правочини в парі $€$ частиною юридичного механізму виникнення або переходу суб'єктивних цивільних прав, вони також перебувають у визначеній континуальній та детермінуючій взаємодії між собою. Зобов'язально-правовий правочин вчиняється раніше і слугує підставою для вчинення розпорядчого правочину.

Спробу підкреслити самостійність розпорядчого правочину можна побачити в оперуванні терміном «договір» відносно зобов'язально-правової та речово-правової частин відповідного механізму, зокрема «договір купівлі-про- 


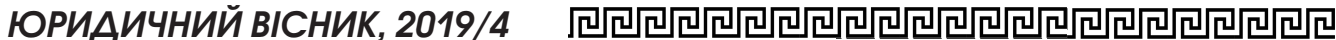

дажу» та «договір традиції» $[5$, с. $37-38]$ або «речовий договір» $[3$, с. $7 ; 14]$, що відповідають зобов'язально-правовому та речово-правовому правочинам відповідно. Однак використання терміну «договір» стосовно двох правочинів в межах загальної спрямованості на їх розмежування також підкреслює існування між ними спільних рис.

«Вразливі місця» принципу роз'єднання демонструються вольовим елементом абстрактного речово-правового (розпорядчого) правочину.

В цілому у відокремленні від принципів роз'єднання та абстракції конструкція абстрактного правочину $€$ життєздатною і підвищує оперативність цивільного обороту речі шляхом спрощення процедури виникнення та переходу суб'єктивних цивільних прав на неї, виключення з відповідних юридичних механізмів певних формальностей. Зокрема, в якості абстрактних правочинів в юридичній літературі розглядаються акцепт векселя, аваль, банківська гарантія [7, с. 14-17], видача цінних паперів на пред’явника тощо. Для всіх зазначених правочинів характерне твердження Ю. П. Єгорова, що 3 урахуванням корисності акту поведінки в цивільному обороті законодавець наділяє його характером правочину і при неясності каузи [8, с. 104]. Відповідні правочини відзначаються простотою форми, чіткістю та однозначністю. Іхх вчинення призводить до результату незалежно від спрямованості волі особи, оскільки вони не можуть породжувати інших наслідків ніж ті, що передбачені законом для їх вчинення.

Однак, законодавець досить вибірково відноситься до абстрактності правочинів і обмежує сферу їх вчинення однозначними i чіткими ситуаціями, що не допускають різнорозуміння, оскільки в протилежному випадку створюються загрози для стабільності цивільного обороту. Абстрактність правочину може вносити в механізми виникнення, переходу та припинення суб'єктивних цивільних прав елемент юридичної невизначеності, оскільки вольовий компонент правочину виноситься за його межі і не розглядається в якості істотної умови відповідного акту поведінки [8, с. 104]. В контексті розмежування зобов'язального та речового правочинів механізму виникнення або переходу суб'єктивних цивільних прав справедливим є твердження О. А. Сурженко, що сама по собі передача майна недостатня для кваліфікації його наслідків, оскільки такі наслідки можуть визначатись лише підставою для передання. В силу того, що майно передається і за договором купівлі-продажу, і за договором оренди, і за договором зберігання, це не означає, що у всіх цих випадках наслідками передачі буде набуття права власності особою на річ [9].

Саме тому ще в римському праві на вольовий компонент речово-правового правочину звертали особливу увагу. Речово-правовий елемент механізму переходу суб'єктивних цивільних прав називався традицією [3, с. 7 ; 9] (лат. traditio). Саме traditio після відміни mancipatio та in jure cessio стало загальною формою та способом переходу права власності на всі речі. Римське право визначало, що самого лише договору недостатньо для зміни суб'єкта права власності. За ним повинен слідувати акт передачі права (traditio) за яким особа, яка передає право, визнає право власності набувача на річ, що передається, а набувач визнає річ своєю. Однак римські юристи визнавали, що угода між передаючим та одержуючим в якій втілюється спільне бажання $є$ justa causa traditionis і являє собою умову без якої неможливий перехід права власності шляхом traditio [10, с. 111-112].

Неможливість ігнорування зв'язку між зобов'язально-правовим та речово-правовим правочинами призводить до висновку, що зобов'язальний правочин $є$ каузальним і спрямовується на досягнення певного результату в той час як розпорядчий правочин слугує тій же меті у зв'язку з чим у нього 
немає окремої самостійної каузи або мети. Розпорядчий правочин спрямовується на досягнення мети зобов'язального правочину, а його абстрактність означає, що 3 його змісту неможливо встановити 3 якою метою він вчиняється [5, с. 35].

3 наведеного слідує пов'язаність зобов'язально-правового та речово-правового правочинів в контексті принципів роз'єднання та абстракції, зокрема в аспекті вольового елементу. 3 цього приводу обгрунтованим виявляється припущення С. I. Шимон, що у випадку, якщо трактувати, наприклад, передання речі самостійним правочином, то його правовий наслідок - виникнення права власності - не має співпадати 3 наслідком головного правочину, на підставі якого здійснюється передача речі. Звідси слід було б вважати, що правочин з купівлі-продажу має на меті виникнення обов'язків 3 передання речі, але ще не виникнення права власності [11, с. 1049]. При цьому як справедливо зазначає Л. В. Криволапова, правочин є вольовою дією і при цьому ця воля доноситься до інших осіб зовнішньою формою волевиявленням. У зв'язку з цим розпорядчий правочин в переважній більшості випадків має своєю основою договір [12, с. 263, 264].

3 наведеного напрошується логічне питання стосовно доцільності розмежування зобов'язально-правового та речово-правового правочинів в контексті принципу роз'єднання.

Очевидним $є$ те, що вчинення розпорядчого правочину без зобов'язально-правової частини може лише перенести володіння, однак не спричиняє перехід права власності або виникнення у набувача похідних речових прав, оскільки його вольовий елемент залишаться невизначеним, а він необхідний для кваліфікації правочину саме як такого, що спричиняє визначені наслідки. В цьому вбачається факультативний (допоміжний) характер речово-правового правочину по відношенню до зобов'язально-правового. Адже перший не може існувати без другого.
Крім того, якщо зважати на те, що зобов'язально-правовий елемент є правочином, тобто вольовою дією, спрямованою на виникнення, перехід або припинення суб'єктивних цивільних прав, то звідси має слідувати, що він породжує відповідні права, зокрема право вимоги. А якщо так, тоді це право вимоги забезпечується захистом. Тому, якщо особа, яка передає права, ухиляється від вчинення розпорядчого правочину, у набувача після вчинення зобов'язально-правового правочину повинна існувати можливість набути права в обхід розпорядчого правочину. В протилежному випадку втрачається сам сенс розмежування зобов'язально-правового та речово-правового правочинів, адже наслідком першого є лише виникнення можливості вчинити другий. Така його цінність є суперечливою. Хоча і вона підкреслює зв'язок між двома відповідними компонентами.

Висновки і перспективи подальших досліджень. Узагальнюючи викладене вище необхідно зазначити, що одним 3 ключових положень, які наводять вчені правники на користь принципів роз'єднання та абстракції, $€$ надання добросовісному набувачу суб'єктивних цивільних прав більш високого рівня захищеності порівняно 3 традиційною «моноправочинною» системою, яка не передбачає здійснення такого поділу. В якості захисної переваги принципу абстракції розглядається необхідність ретельного, поетапного розгляду обставин справи для забезпечення прав учасників відповідних правовідносин, зокрема окремого визнання недійсним зобов'язально-правового та речово-правового (розпорядчого) правочинів [4, с. 214]. Проте, в світлі зазначеного необхідно зважати і на те, що підстава недійсності зобов'язально-правового правочину може одночасно бути і підставою недійсності речово-правового, зокрема у випадку, коли обидва правочини вчиняються недієздатною особою [5, с. 37] або, якщо має місце помилка стосовно предмету правовідносин [1, с. 154]. 




Наведене вище створює підгрунтя для дискусій 3 приводу життєздатності і доцільності запровадження принципів роз'єднання та абстракції, якими забезпечується поділ правочинів на зобов'язально-правові та речово-правові як невід'ємних елементів виникнення або переходу суб'єктивних цивільних прав на речі. Вбачається, що речово-правовий правочин має похідний характер від зобов'язально-правової складової, оскільки детермінується ї каузою і є ii логічним продовженням в межах розвитку механізмів виникнення та переходу суб'єктивних цивільних прав. Вольовий елемент речово-правового компоненту повністю визначається зобов'язально-правовим. 3 цього виникає питання, як неправомірна або недостатня правова підстава може викликати повністю правомірний та повний юридичний наслідок?

Якщо ж йти тим шляхом, що абстрактний речово-правовий правочин $€$ незалежним від зобов'язально-правового, тоді підкреслюється штучність їх розмежування. Іншими словами, якщо після вчинення зобов'язально-правового правочину у формі укладення договору купівлі-продажу вчиняється речово-правовий правочин з передачі речі у тимчасове користування, то в такому разі стає очевидним недоцільності існування зобов'язально-правового елементу і повна незалежність розпорядчого правочину від нього. Якщо ж вчинення другого без належної justa causa обумовлює його недійсність або неспричинення ним необхідного правового наслідку, то в такому разі стає очевидним його залежність від зобов'язально-правового правочину. Звідси і питання: в чому полягає необхідність їх розмежування?

Більше того, в контексті захисту виникає питання стосовно доцільності існування «дворівневої» процедури його здійснення. По-перше, сам факт розмежування двох видів правочинів вимагає від учасників відповідних пра- вовідносин підвищеної уваги до їх чинності, а, по-друге, дворівневий захист, це, відповідно, подвійна тривалість, подвійні витрати, подвійне навантаження на суди у відповідних категоріях справ. Очевидною $є$ та обставина, що в такому разі захист втрачає в оперативності застосування. Переваги в такому підході в порівнянні 3 «однорівневим» захистом досить складно вгледіти, особливо в контексті можливості суду вирішити питання в рамках однієї юридичної процедури, а не декількох і зважаючи на те, що законодавець може підвищити рівень забезпеченості прав набувачів шляхом обмеження випадків застосування відповідних способів захисту суб'єктивних цивільних прав відчужувачів.

3 наведеного слідує, що концепція принципів роз'єднання та абстракції $€$ дискусійною i потребує зваженого підходу при іï впровадженні в якості базової нормативної моделі механізмів виникнення та переходу суб'єктивних цивільних прав.

Стаття присвячена розгляду основних наукових положень щодо розмежування зобов'язально-правового та речово-правового правочинів в юридичних механізмах виникнення ma переходу суб'єктивних цуивільних прав в контексті принципів роз'єднання та абстракиї. Встановлено, що вони є результатом осмислення німецькими вченими-пандектисками юридичного механізму виникнення суб'єктивних цивільних прав на підставі цивільно-правового договору. Базуючись на изих принципах, зокрема німецьке цивільне законодавство розмежовуе зобов'язально-правовий $i$ речово-правовий правочини як підстави перенесення титулу. Для прикладу, укладення договору купівлі-продажу являе собою зобов'язально-правовий акт. За німецьким цивільним законодавством його не достатньо для переходу прав. Наступною стадією є вчинення речово-правового правочину - домовленості про перехід прав, 
що вчиняється продавием $і$ покупием i може мати форму, зокрема фактичної передачі речі.

Поряд із иим, в сучасних умовах концепція принципів роз'єднання та абстракиії є предметом дискусії. Одним із ї̈ вразливих місць вольовий аспект. Адже відповідно до загальноприйнятої наукової позиції зобов'язально-правовий правочин є каузальним і спрямовується на спричинення певних юридичних наслідків. Поряд із иим, речово-правий правочин вчиняється з тією самою метою, однак не має своєї власної каузи. У зв'язку з иим співвідношення між обома правочинами породжуе питання необхідності існування речово-правового акту як окремого правочину в юридичному механізмі виникненні $i$ переходу суб'єктивного цивільного права. Сучасні вчені зазначають, що подвійність правочинів забезпечуе подвійний захист учасників відповідних правовідносин. У випадку недійсності зобов'язально-правового правочину речово-правовий зберігає свою чинність. Тому реституйія може мати місие лише у разі визнання недійними обох правочинів.

Автор резюмує, що розмежування зобов'язально-правового $i$ речово-правового правочинів змушуе учасників відповідних правовідносин бути більш уважними при їх вчиненні. Крім того, таке розмежування подвоюе організаційнi $i$ фінансові витрати на передачу відповідного суб'єктивного ичивільного права $і$ створюе додаткові навантаження на суди у випадку виникнення юридичного конфлікту. У зв'язку з иим необхідність розменування зобов'язально-правового і речово-правового правочинів в механізмі виникнення $i$ переходу суб'єктивних циивільних прав наразі залишається дискусійною.

Ключові слова: виникнення прав, перехід прав, правочин, зобов'язально-правовий правочин, речово-правовий правочин, роз'єднання, абстракція
Pohrebniak V. The relationship between contractual and proprietary transactions with respect to principles of division and abstraction The article is devoted to consideration the main scientific provisions concerning distinction of contractual and proprietary acts in legal mechanism of establishment and transfer of subjective civil rights with regard to principles of division and abstraction. Establishing such principles is a result of comprehension by German pandectists the legal mechanism of establishing civil rights on the basis of contract. Basing on these principles German civil legislation divides contractual and proprietary transactions as ground for title transfer. For example conclusion salespurchase contract is a contractual act. But it is not enough for right transfer according to German civil legislation. The next stage is proprietary act agreement of right transfer concluded between salesman and purchaser that can take shape of material act of thing transfer.

But in actual circumstances principles of division and abstraction generate discussion. One of the main weak spots of analyzed concept is will. According to common theoretical position contractual act is causal and aims at effect some consequence. At the same time proprietary act follows the same aim but doesn't have own causa. Relation between both transactions raises the question of necessity of proprietary act as separate deal in legal mechanism of establishment and transfer of subjective civil rights. Modern scientists note that double transactions provide double protection of dealing parts rights. In case of invalidation of contractual act the proprietary act saves its validity. In this point of view restitution can be caused only when both acts recognized as invalid.

The author concludes that division of contractual and proprietary 


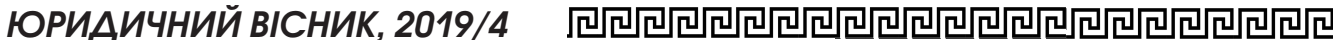

transactions makes necessitate dealing parts to be more attentive when committing them. Moreover such division doubles all organizational and financial expenses on right transfer and loads on courts when juridical conflicts arise. That's why necessity of distinction contractual and proprietary transactions in legal mechanism of establishment and transfer of subjective civil rights is staying debatable nowadays.

Key words: right establishment, right transfer, transaction, contractual transaction, proprietary transaction, division, abstraction

\section{Література}

1. Таш'ян P. I. Недійсність правочинів та ї̈ правові наслідки у иивільному праві Німеччини. Вісн. Нац. акад. прав. Наук України. 2017. № 1 (88). С. 152-160.

2. Фогель В. А. Недвижимое имущество как объект добросовестного приобретения (по праву Германии). Объекты гражданского оборота: сб. статей / отв. ред. М. А. Рожкова. Москва: Cтатут, 2007. С. 379-393. (Анализ современного права).

3. Балаценко М. Місие речового договору в механізмі реєстрації речових прав на нерухоме майно. Укр. комери. право. 2015. № 14. С. 6-14. (Державна реєстраиія речових прав на нерухоме майно та ї обтяжень).

4. Харченко Г. Г. Приниипи роз'єднання та абстракиіі у речовому праві. Часопис Київ. ун-ту права. 2011. № 4. С. 211- 214 .

5. Варул П. А. Распорядительные сделки. Сборник научных статей в честь 60-летия Е. А. Крашенинникова: сб. науч. ст. / отв. ред. П. А. Варул. Ярославль: ЯрГУ, 2011. С. 34-42.

6. Яроиький В. Л. Проблеми використання формально-догматичного методу в сучасних иивілістичних дослідженнях. Проблеми подальшого вдосконалення приватноправових механізмів набуття, передачі, здійснення та захисту суб'єктивних иивільних прав: матеріали наук.-практ. конф., присвяч. пам'яті проф. Ч. Н. Азімова (Харків, 21 грудня 2017 р.). Харків, 2017. C. 5-13.

7. Власова A. В. Абстрактные обязательственные договоры. Очерки по торговому праву: сб. науч. тр. / под. ред. E. A. Крашенинникова. Ярославск. гос. ун-т. Ярославль, 2002. Bып. 9. С. 9-19.

8. Егоров Ю. П. Классификаиия сделок. Вестн. Омск. ун-та. Серия «Право». 2008. № 3 (16). C. 100-111.

9. Сурженко О. А. Засоби фіксації переходу права власності за договором. Теорія $i$ практика правознавства: електрон. наук. фахове вид. 2013. Bun. 2. URL: http:// nbuv.gov.ua/UJRN/tipp_2013_2_9 (dama звернення: 17.12.2018).

10. Дормидонтов Г. Ф. Система римского права: Вещное право. студ. Изд. Казань: Типо-литография Импер. ун-та. 1913. 204 c.

11. Шимон С. І. Відчуження майнового права та кониепт речового (розпорядчого) правочину в цивільному праві. Форум права. електрон. наук. фахове вид. 2011. № 2. C. 1048-1054. URL: http: / / nbuv.gov. ua/UJRN/FP_index.htm_2011_2_172(dama звернення: 17.12.2018).

12. Криволапова Л. В. О месте распорядительных сделок в системе юридических фактов. Известия Оренбург. гос. аграр. ун-та. 2012. № 36-1, T.4. С. 262-265. 